\title{
Number of germ cells and meiotic prophase stages in fetal rat ovaries cultured in vitro
}

\author{
J. Prépin, C. Gibello-Kervran, G. Charpentier and A. Jost \\ Collège de France, Laboratory of Developmental Physiology, 11, place Marcelin Berthelot, \\ 75231 Paris Cedex 05, France
}

\begin{abstract}
Summary. Ovaries from 13.5-day-old rat fetuses were cultured in vitro in a hormone-free medium for up to 8 days. The number of germ cells increased during the first 4 days and then sharply decreased. The initial decrease was concomitant with the first leptotene stages. All stages of meiotic prophase progressively appeared in the remaining germ cells.
\end{abstract}

\section{Introduction}

In developing fetal ovaries the number of germ cells passes through a maximum followed by a marked decrease (rat: Beaumont \& Mandl, 1962; Mauléon, 1978; guinea-pig: Ioannou, 1964; calf: Erickson, 1966; pig: Black \& Erickson, 1968; man: Baker, 1963; marsupials: Alcorn \& Robinson, 1983). The decrease in the number of germ cells can occur when the first zygotene (rat), pachytene (calf, pig, man, marsupial) or diplotene (guinea-pig) stages appear.

In the rat fetus the total number of germ cells was counted in histological sections by Beaumont \& Mandl (1962) and by Mauléon (1978). They report a maximum number at 18.5 or 18 days respectively. A 6-fold increase occurs between Days 14.5 and 18.5 followed by a progressive decrease until several days after birth. The appearance of the first leptotene figures was reported to occur on Day 16 (Jagiello, Downey \& Ducayen, 1982), Day 17.5 (Beaumont \& Mandl, 1962; Rivelis, Prépin, Vigier \& Jost, 1976), Day 17.75 (Bézard \& Mauléon, 1981), or Day 18 (Hilscher \& Hilscher, 1972). These differences in timing result probably from different ways of dating the beginning of pregnancy (not reported by some authors) and from different histological procedures.

The control of the multiplication of the ovarian germ cells followed by the disappearance of many of them is still unknown. Multiplication in vitro of isolated germ cells from fetal mouse ovaries has been reported (de Felici \& McLaren, 1983) and germ cells in primordia of rat ovaries cultured in vitro in a synthetic medium have entered the meiotic prophase (Rivelis et al., 1976). The aim of the present experiments was to verify whether, in a hormone-free synthetic medium, the number of germ cells in the rat fetal ovary also passes through a maximum, and if so, whether there is a relation between the stages of meiotic prophase and the decrease in the number of germ cells.

\section{Materials and Methods}

Fetal ovaries. Female rats from the Wistar C.F. strain (stock from the CNRS, France), were caged with a male for 1 night. Pregnant animals were recognized by palpation 13.5 days later. Time zero of pregnancy was assumed to occur at $02: 00 \mathrm{~h}$ on the night of pairing when ovulation and fertilization occur (Jost \& Picon, 1970). At precisely 13 days plus $13 \mathrm{~h}$ after fertilization, the females were killed by cervical dislocation, and the fetuses were rapidly removed from the uterus and their sex was determined by applying the sex chromatin test to cells of the amniotic membrane (see Jost, 
1972). Both gonads and their associated mesonephroi were aseptically dissected from female fetuses and cultured in vitro.

Cultures. The explants were cultured in dishes (Falcon Plastics, No3037, Becton, Dickinson and Co, Cockeysville, MD 21030, USA), immersed in 0.8 ml Medium CMRL 1066 (Eurobio, Paris), containing 250 i.u. benzyl-penicillin/ml (Specilline G: Specia, 75008 Paris, France) and $100 \mathrm{mg}$ streptomycin sulphate $/ \mathrm{ml}$ (Specia). The temperature was $36 \pm 1^{\circ} \mathrm{C}$ and the gas mixture was $95 \%$ air $+5 \% \mathrm{CO}_{2}$. The culture period varied from 2 to 8 days in unchanged medium. Since explantation and fixation were made at the same hour of the day, in the text we shall speak of 13.5-day-old fetuses.

Counting germ cells. The explants were fixed in Bouin's fluid and embedded in paraffin wax. Serial sections were cut at $5 \mu \mathrm{m}$, and stained with haematoxylin and eosin. The germ cells were identified according to their large size, round and lightly staining nucleus of $6-7 \mu \mathrm{m}$ in diameter, and characteristic nuclear appearance when in meiotic prophase (Franchi, Mandl \& Zuckerman, 1962). Oogonia and meiotic germ cells were counted in all serial sections. Because the sections were $5 \mu \mathrm{m}$ thick and the nuclear diameter is $6-7 \mu \mathrm{m}$, it was possible to count the same cell twice. The counts are therefore overestimates. Since the nuclear diameter was the same at the different stages studied and since the technique was the same for all cultures, no correction factor was introduced in the comparisons.

Identification of the meiotic stages. Other ovaries, cultured as indicated above, were treated according to the technique of Luciani \& Stahl (1971) to disperse the cells. The cell suspensions were observed after spreading on slides and Giemsa staining. The meiotic stages were identified according to Stahl, Luciani \& Devictor-Vuillet (1973); oogonia could not be recognized with certainty in such preparations.

\section{Results}

Number of germ cells in the explanted ovaries

The average number of germ cells in histological sections after various culture periods is shown in Text-fig. 1. In 5 pairs of Day-13.5 ovaries that were not cultured (Pl. 1, Fig. 1), there were $2306 \pm$ 259 (s.e.m.) germ cells per pair of ovaries but another $178 \pm 43$ germ cells had not yet reached the gonadal primordium and were seen in the dorsal mesentery or in the mesonephric mesenchyme adjacent to the gonads. In the explants studied after 2-8 days in vitro, extra-gonadal germ cells were no longer detectable. It cannot be ascertained whether the extra-gonadal germ cells seen on Day 13.5 reached the gonads or degenerated during the first 2 days after explantation.

The number of germ cells increased very rapidly on the $3 \mathrm{rd}$ and 4 th day in vitro (P1. 1, Fig. 2), displaying a doubling in their number per $24 \mathrm{~h}$. During the 5 th day their average number decreased to $50 \%$ and many degenerating cells were seen. Although a slower decrease occurred for the next 3

\section{PLATE 1}

Histological sections of ovaries from 13-5-day-old rat fetuses cultured for various periods of time.

Fig. 1. An ovary on the day of explantation; 3 germ cells are arrowed. $\times 565$.

Fig. 2. An ovary after 4 days of culture; note the increase in size and the great number of germ cells (arrowed). $\times 565$.

Fig. 3. An ovary after 5 days of culture, showing degenerating germ cells (arrows), oogonia (O) and zygotene nuclei $(Z) . \times 1400$.

Fig. 4. Section of an ovary cultured for 8 days, showing zygotene and pachytene stages. $\times 1400$. 
PLATE 1
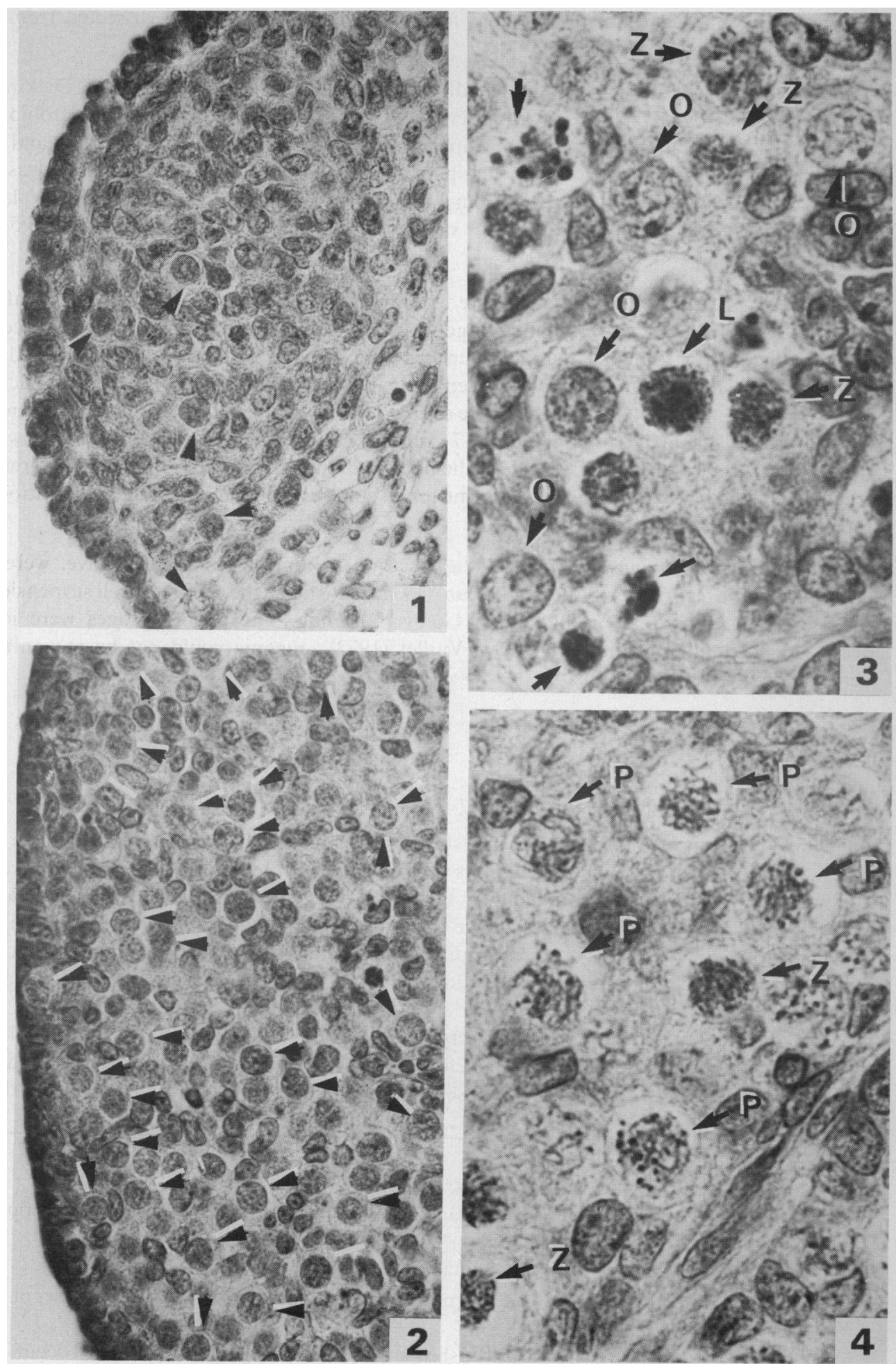


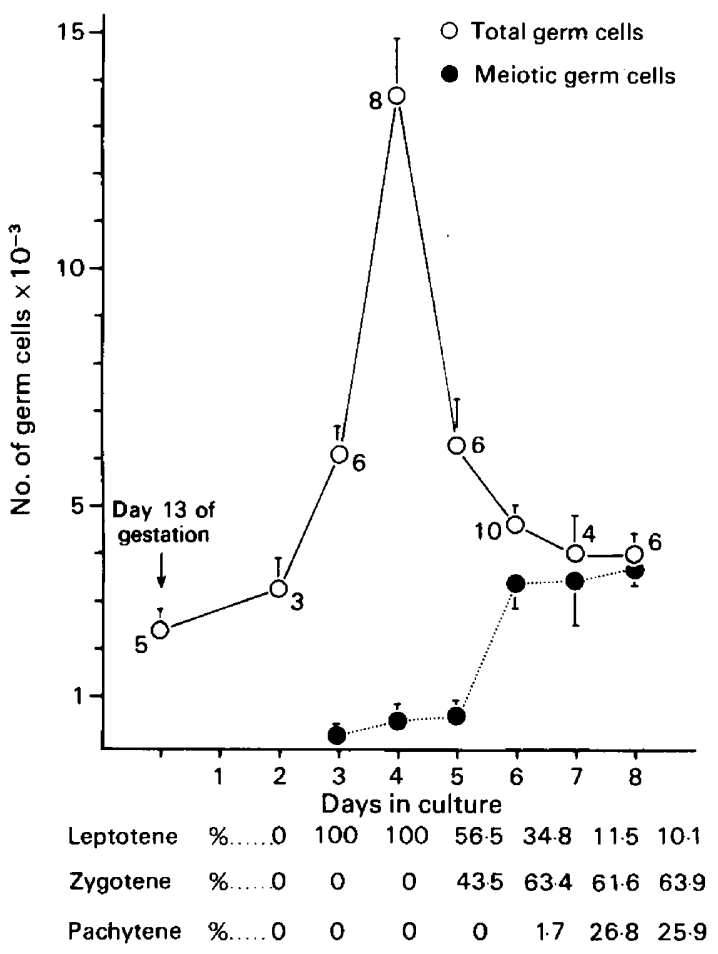

Text-fig. 1. Total numbers of germ cells and of meiotic germ cells counted in histological sections of ovaries from 13.5-day-old rat fetuses cultured for various numbers of days. Values are mean \pm s.e.m. for the no. of explants indicated. The percentages of the stages of the meiotic prophase counted in dispersed cells from 13.5-day-old ovaries after culture are also shown.

Table 1. Total number of germ cells and number of meiotic cells in ovaries from 13.5-day-old fetuses, cultured in the same dishes in unchanged medium and with the second pair of ovaries introduced 3 days after the first pair

\begin{tabular}{|c|c|c|c|c|}
\hline & \multicolumn{4}{|c|}{ Number of germ cells per pair of ovaries: } \\
\hline & \multicolumn{2}{|c|}{ In 1st pair $(13 \cdot 5+7$ days $)$} & \multicolumn{2}{|c|}{ In 2 nd pair $(13.5+4$ days $)$} \\
\hline & Total & Meiotic & Total & Meiotic \\
\hline & $\begin{array}{l}5150 \\
7037 \\
3383 \\
3147 \\
4346\end{array}$ & $\begin{array}{l}4465 \\
6192 \\
2232 \\
2454 \\
3085\end{array}$ & $\begin{array}{l}10155 \\
14732 \\
12583 \\
18820 \\
11944\end{array}$ & $\begin{array}{r}61 \\
88 \\
88 \\
94 \\
144\end{array}$ \\
\hline Mean \pm s.e.m. & $4612 \pm 703$ & $3685 \pm 737$ & $13646 \pm 1485$ & $95 \pm 42$ \\
\hline
\end{tabular}

days, the final number after 8 days in vitro still surpassed by $50 \%$ the number of germ cells present at the time of explantation, i.e. at 13.5 days of age.

Although the decrease in the number of germ cells was similar to that observed at approximately the same age in vivo, the following experiment was performed to verify that it did not result from an exhaustion or any other alteration of the culture medium. In 5 experiments, 13.5-day- 
old ovarian primordia were introduced into dishes in which another set of 13.5-day-old primordia had already grown for 3 days. The two sets of ovaries were permitted to develop for 4 more days, reaching a 'final age' of 17.5 and 20.5 days, respectively. At the end of experiment the number of germ cells in the older ovaries was as low as that after 7 days of culture, whereas it had increased normally in the younger set of ovaries (Table 1). The decrease in the number of germ cells in the older ovaries occurred concomitantly with the increase in the younger ovaries in the same medium.

\section{Number of meiotic germ cells in explanted ovaries}

In histological sections a few leptotene figures could be seen after 3 days in vitro. During the next $24 \mathrm{~h}$ the number of leptotene figures had increased about 5 times while the number of germ cells increased only 2 -fold (Text-fig. 1). The number of germ cells entering meiotic prophase increased more rapidly than the total number of germ cells. During the 5 th day in vitro the number of meiotic germ cells remained approximately constant in spite of the striking reduction of the total number of germ cells. During the next 3 days in vitro almost all of the remaining germ cells had entered meiosis (Pl. 1, Figs 3 \& 4).

\section{Stage of meiotic prophase obtained in vitro}

Since the stages of meiotic prophase are somewhat difficult to identify in routine histological sections, they were studied on dissociated cells. Because the recovery of the germ cells is low, the figures were expressed as percentages of the total number of cells recovered (Text-fig. 1).

After 3 and 4 days in vitro, i.e. during the period of major multiplication of the germ cells, only leptotene nuclei were present. The appearance of zygotene stages was concomitant with the rapid decrease of the germ cells on the 5th day in vitro. The first pachytene oocytes were seen the next day, when zygotene nuclei had become predominant. After 7 days, the percentages of leptotene nuclei decreased and of pachytene nuclei increased while the total number of germ cells and of oocytes in zygotene remained constant. This indicates a simultaneous passage from leptotene to zygotene and from zygotene to pachytene stages.

\section{Discussion}

The present experiments, in agreement with those of Challoner (1975), demonstrate that multiplication of the germ cells occurs in the fetal ovary cultured in vitro in a serum-free synthetic medium, without requiring any extra-gonadal or extra-mesonephric stimulus other than the components of the synthetic medium. An influence of the mesonephros and of the rete on the initiation of meiosis has been postulated (Byskov \& Grinsted, 1981) but as yet there are no precise data concerning such an influence on the number of germ cells.

In addition, we have shown that, in vitro, the number of germ cells passes through a maximum followed by a decrease, in a way that resembles the kinetics observed in vivo (Beaumont \& Mandl, 1962; Mauléon, 1978). However, two differences are obvious. First, the maximum number of germ cells obtained in vitro is 6-10 times less than that in vivo; this finding supports and extends earlier indications of a reduced number of germ cells in fetal ovaries cultured in vitro (Baker \& Neal, 1973; Challoner, 1975; Stein \& Anderson, 1981). The possible wastage of germ cells that had not yet reached the gonad at the time of explantation could partly explain the difference. The second difference we found is that the decrease in the number of germ cells occurs 1 day earlier in vitro than in vivo, at least if one accepts the comparison of age in vivo and 'total age' of the culture, i.e. 13.5 days in utero $+n$ days in vitro. Moreover, the decrease is more abrupt in vitro, the reduction being $50 \%$ in $24 \mathrm{~h}$, compared with $16 \%$ in vivo according to Beaumont \& Mandl (1962). The percentages of decrease become similar during the subsequent days. 
Beaumont \& Mandl (1962) explained the reduction of the number of germ cells by degeneration of dividing oogonia ("atretic divisions") or oocytes at the zygotene or pachytene stage ("Z cells"). In vitro, it is clear from the present study that the greatest phase of degeneration precedes the appearance of the zygotene figures. From the data shown in Text-fig. 1, it appears that, during the 6th day in vitro, the number of cells progressing into meiotic prophase exceeds the number of disappearing cells. After 6 days in vitro almost all the surviving germ cells have passed through the zygotene and pachytene stages. Many germ cells seem to degenerate before reaching the leptotene stage, i.e. long before ovarian follicles differentiate. It is not yet possible to explain why the early phases of meiosis are so critical, both in vivo and in vitro, for the survival of the oocytes.

We thank Ms O. Locquet and Mrs M. Solvar for their excellent help in preparing histological sections, and Mr R. Urbe for providing the exactly dated pregnant animals. This work was supported by grant No ASP 960017 from the Centre National de la Recherche Scientifique.

\section{References}

Alcorn, G.T. \& Robinson, E.S. (1983) Germ cell development in female pouch young of the tammar wallaby (Macropus eugenii). J. Reprod. Fert. 67, 319 . 325.

Baker, T.G. (1963) A quantitative and cytological study of germ cells in human ovaries. Proc. R. Soc. B 158, 417-433.

Baker, T.G. \& Neal, P. (1973) Initiation and control of meiosis and follicular growth in ovaries of the mouse. Annls Biol. anim. Biochim. Biophys. 13, 137-144.

Beaumont, H.M. \& Mandl, A.M. (1962) A quantitative study of oogonia and oocytes in the foetal and neonatal rat. Proc. R. Soc. B 155, 557-579.

Bézard, J. \& Mauléon, P. (1981) Ultrastructural changes in mammalian oocytes at the beginning of meiotic prophase with special reference to the nuclear pores studied by freeze-fracture technique. In Development and Function of Reproductive Organs, pp. 93-103. Eds A. G. Byskov \& H. Peters. Excerpta Medica/ Elsevier/North Holland, Amsterdam.

Black, J.L. \& Erickson, B.H. (1968) Oogenesis and ovarian development in the prenatal pig. Anat. Rec. $161,45-56$.

Byskov, A.G. \& Grinsted, J. (1981) Production of germ cells and regulation of meiosis. In Bioregulators of Reproduction, pp. 109-117. Eds G. Jagiello \& H. J. Vogel. Academic Press, New York.

Challoner, S. (1975) Studies of oogenesis and follicular development in the golden hamster. (2) Initiation and control of meiosis in vitro. J. Anat. 119, 149-156.

de Felici, M. \& McLaren, A. (1983) In vitro culture of mouse primordial germ cells. Expl Cell. Res. 144, 417-427.

Erickson, B.H. (1966) Development and radio-response of the prenatal bovine ovary. J. Reprod. Fert. 11, 97105.

Franchi, L.L., Mandl, A.M. \& Zuckerman, S. (1962) The development of the ovary and the process of oogenesis. In The Ovary, 1st edn, vol. 1, pp. 1-88. Ed. S. Zuckerman. Academic Press, New York.
Hilscher, W. \& Hilscher, B. (1972) Comparative study on oogenesis and prespermatogenesis in the Wistar rat under normal and pathological conditions. Annls Biol. Anim. Biochim. Biophys. 13, 128-136.

Ioannou, J.M. (1964) Oogenesis in the guinea-pig. $J$. Embryol. exp. Morph. 12, 673-691.

Jagiello, G., Downey, S. \& Ducayen, M. (1982) Xchromosome heteromorphism and appearance of meiosis in the rat fetal ovary. Devl Biol. 90, 223-225.

Jost, A. (1972) Données préliminaires sur les stades initiaux de la différenciation du testicule chez le rat. Archs Anat. microsc. Morph. exp. 61, 415-438.

Jost, A. \& Picon, L. (1970) Hormonal control of foetal development and metabolism. In Advances in Metabolic Disorders, vol. 4, pp. 123-184. Eds R. Levine \& R. Luft. Academic Press, New York.

Luciani, J.M. \& Stahl, A. (1971) Etude des stades de début de la méiose chez l'ovocyte foetal humain. Bull. Ass. Anat. 151, 445-458.

Mauléon, P. (1978) Ovarian development in young mammals. In Control of Ovulation, pp. 141-158. Eds D. B. Crighton, N. B. Haynes, G. R. Foxcroft \& G. E. Lamming. Butterworths, London.

Rivelis, C., Prépin, J., Vigier, B. \& Jost, A. (1976) Prophase méiotique dans les cellules germinales de l'ébauche ovarienne de rat cultivée in vitro en milieu anhormonal. C. r. hebd. Séanc. Acad. Sci., Paris, D 282, 1429-1432.

Stahl, A., Luciani, J. M. \& Devictor-Vuillet, M. (1973) Etude chromosomique de la méiose. In Les Accidents Chromosomiques de la Reproduction, pp. 197-218. Eds A. Boué \& Ch. Thibault. INSERM, Paris.

Stein, L.E. \& Anderson, E. (1981) In vitro analysis of ovarian differentiation and the initiation of meiosis in the rat. Acta anat. 110, 189-205. 